\title{
Phototherapy and photochemotherapy in dermatology. Recommendations of the Polish Dermatological Society
}

\author{
Fototerapia i fotochemoterapia w dermatologii. Rekomendacje Polskiego \\ Towarzystwa Dermatologicznego
}

\author{
Waldemar Placek', Andrzej Kaszuba², Aleksandra Lesiak², Joanna Maj ${ }^{3}$, Joanna Narbutt², \\ Agnieszka Osmola-Mańkowska ${ }^{4}$, Hanna Wolska ${ }^{5}$, Lidia Rudnicka ${ }^{6}$ \\ 'Department of Dermatology, Sexually Transmitted Diseases and Clinical Immunology, Collegium Medicum, University of Warmia \\ and Mazury, Olsztyn, Poland \\ 2Department of Dermatology, Children's and Oncological Dermatology, Medical University in Lodz, Poland \\ ${ }^{3}$ Department of Dermatology, Venereology and Alergology, Wroclaw Medical University, Poland \\ ${ }^{4}$ Department of Dermatology, Poznan University of Medical Sciences, Poland \\ ${ }^{5}$ Specialist Clinic - High-Med, Warsaw, Poland \\ ${ }^{6}$ Department of Dermatology, Medical University of Warsaw, Poland \\ 'Katedra i Klinika Dermatologii, Chorób Przenoszonych Drogą Płciową i Immunologii Klinicznej, Collegium Medicum \\ Uniwersytetu Warmińsko-Mazurskiego w Olsztynie, Polska \\ ${ }^{2}$ Katedra i Klinika Dermatologii, Dermatologii Dziecięcej i Onkologicznej Uniwersytetu Medycznego w Łodzi, Polska \\ ${ }^{3}$ Katedra i Klinika Dermatologii, Wenerologii i Alergologii Uniwersytetu Medycznego we Wrocławiu, Polska \\ ${ }^{4}$ Katedra i Klinika Dermatologii Uniwersytetu Medycznego w Poznaniu, Polska \\ ${ }^{5}$ Przychodnia Specjalistyczna - High-Med w Warszawie, Polska \\ ${ }^{6}$ Katedra i Klinika Dermatologiczna Warszawskiego Uniwersytetu Medycznego, Polska
}

Dermatol Rev/Przegl Dermatol 2019, 106, 237-256

DOI: https://doi.org/l0.5।|4/dr.2019.86906

\author{
CORRESPONDING AUTHOR/ \\ ADRES DO KORESPONDECJI: \\ prof. dr hab. n. med. \\ Waldemar Placek \\ Katedra i Klinika Dermatologii, \\ Chorób Przenoszonych \\ Drogą Płciową \\ i Immunologii Klinicznej \\ Collegium Medicum \\ Uniwersytet \\ Warmińsko-Mazurski \\ Olsztyn \\ tel.: +48601915419 \\ e-mail: w.placek@wp.pl
}

\begin{abstract}
Light is a component of the electromagnetic waves. The electromagnetic wave consists of mutually inducible electrical and magnetic components that generate variable electric field. This then turns into magnetic field, causing alternating current to flow. Electromagnetic waves include radio waves, microwaves, infrared light, visible light, ultraviolet light, $\mathrm{X}$-rays and gamma radiation. The length of these waves determines their properties. An increase in wavelength is accompanied by a decrease in its radiation energy. Dermatological phototherapy uses the following types of light: broadband UVB, narrow-band monochromatic UVB, laser UVB, UVA in combination with psoralens - PUVA, UVA1, visible light, monochromatic light within the visible spectrum: violet, yellow, red, deep red and infrared. Phototherapy and photochemotherapy nowadays uses equipment emitting radiation at the following lengths: UVB 311, UVB 313, UVB 308, UVA 320-400 $\mathrm{nm}$ with a peek at $365 \mathrm{~nm}$ and $340-400 \mathrm{~nm}$ UVA1. In Poland, the most commonly used radiation is UVB 311 and UVA $320-400 \mathrm{~mm}$ (mainly with psoralens). Photochemotherapy is a form of treatment by light, in which the effect of ultraviolet in combination with chemical substances acting as photosensitizers (psoralens) is utilized. The term PUVA was introduced in 1974 by Parrish et al. in a publication assessing the results of psoriasis treatment with orally administered 8-methoxypsoralen and wholebody exposure to long-wave UVA radiation. This article contains the recommendations of the Polish Dermatological Society for photoherapy and photochemoterapy in dermatology.
\end{abstract}




\section{STRESZCZENIE}

Światło stanowi jeden z elementów fali elektromagnetycznej. Fala elektromagnetyczna zawiera natomiast dwie składowe: elektryczną i magnetyczną, które indukują się wzajemnie. Właściwości fal elektromagnetycznych zależą od długości fali. Promieniowaniem elektromagnetycznym są: fale radiowe, mikrofale, podczerwień, światło widzialne, ultrafiolet, promieniowanie rentgenowskie i promieniowanie gamma. Wraz ze wzrostem długości fali zmniejsza się energia promieniowania. W fototerapii dermatologicznej wykorzystuje się następujące typy promieniowania: UVB szerokopasmowe, monochromatyczne wąskopasmowe UVB, UVB laserowe, UVA w połączeniu z psoralenami - PUVA, UVA1, światło widzialne, monochromatyczne światło w zakresie pasm widzialnych: fiolet, niebieski, zielony, żółty, czerwony, głęboka czerwień, podczerwień. W fototerapii i fotochemoterapii wykorzystuje się obecnie aparaturę emitującą następujące długości promieniowania: UVB 311, UVB 313, UVB 308, UVA 320-400 nm z pikiem 365 nm i UVA1 o długości 340-400 nm. W Polsce najczęściej stosowane jest promieniowanie UVB 311 i UVA 320-400 mm (głównie z psoralenami). Fotochemoterapia to łączona forma leczenia światłem ultrafioletowym oraz substancjami chemicznymi zwiększającymi wrażliwość skóry na ultrafiolet. Substancje te należą do psoralenów. Termin PUVA został wprowadzony w 1974 roku przez Parrisha i wsp. w pracy oceniającej wyniki leczenia łuszczycy za pomoca podawanego doustnie 8-metoksypsoralenu i naświetlań całej powierzchni skóry długimi promieniami UVA. W tym artykule przedstawiono rekomendacje Polskiego Towarzystwa Dermatologicznego dotyczące stosowania fototerapii oraz fotochemoterapii $\mathrm{w}$ dermatologii.

Key words: phototherapy, photochemotherapy, guidelines.

Słowa kluczowe: fototerapia, fotochemoterapia, rekomendacje.

\section{INTRODUCTION}

Light is a component of the electromagnetic wave. The electromagnetic wave consists of mutually inducible electrical and magnetic components that generate variable electric field. This then turns into magnetic field, causing alternating current to flow. The length of electromagnetic waves determines their properties. Variable-wavelength electromagnetic radiation includes radio waves, microwaves, infrared light, visible light, ultraviolet light, $\mathrm{X}$-rays and gamma radiation. Quantum physics describes electromagnetic radiation in terms of a stream of zero-mass elementary particles known as photons. Photon energy depends on light's wavelength, such that an increase in wavelength is accompanied by a decrease in its radiation energy [1] (fig. 1).

Dermatological phototherapy uses the following types of visible light: broadband UVB, narrow-band monochromatic UVB, laser UVB, UVA in combination with psoralens - PUVA, UVA1, visible light, monochromatic light within the visible spectrum: violet, yellow, red, deep red and infrared.

\section{WPROWADZENIE}

Światło stanowi jeden z elementów fali elektromagnetycznej. Fala elektromagnetyczna zawiera dwie składowe: elektryczną i magnetyczną, które indukują się wzajemnie - zmieniające się pole elektryczne wytwarza zmieniające się pole magnetyczne, a to z kolei wytwarza zmienne pole elektryczne. Właściwości fal elektromagnetycznych zależą od długości fali. Promieniowaniem elektromagnetycznym o różnej długości fali są: fale radiowe, mikrofale, podczerwień, światło widzialne, ultrafiolet, promieniowanie rentgenowskie i promieniowanie gamma. W opisie kwantowym promieniowanie elektromagnetyczne jest traktowane jako strumień cząstek elementarnych nieposiadających masy, zwanych fotonami. Energia każdego fotonu zależy od długości fali; wraz ze wzrostem długości fali zmniejsza się energia promieniowania [1] (ryc. 1).

W fototerapii dermatologicznej wykorzystuje się następujące typy promieniowania świetlnego: UVB szerokopasmowe, monochromatyczne wąskopasmowe UVB, UVB laserowe, UVA $\mathrm{w}$ połączeniu z psoralenami - PUVA, UVA1, światło widzialne, monochromatyczne 


\section{Electromagnetic spectrum}

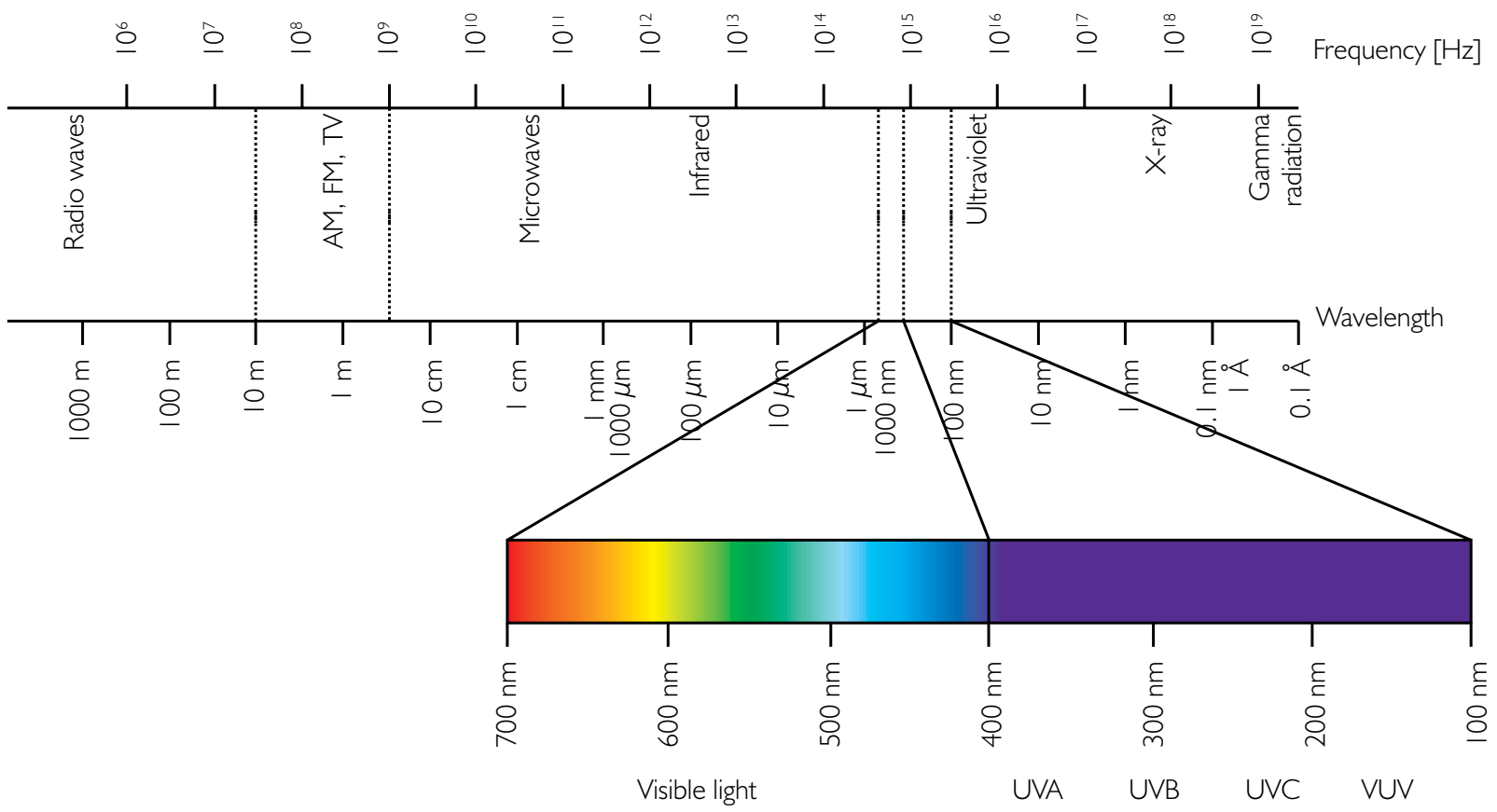

Figure I. Electromagnetic spectrum

\section{Widmo eletromagnetyczne}

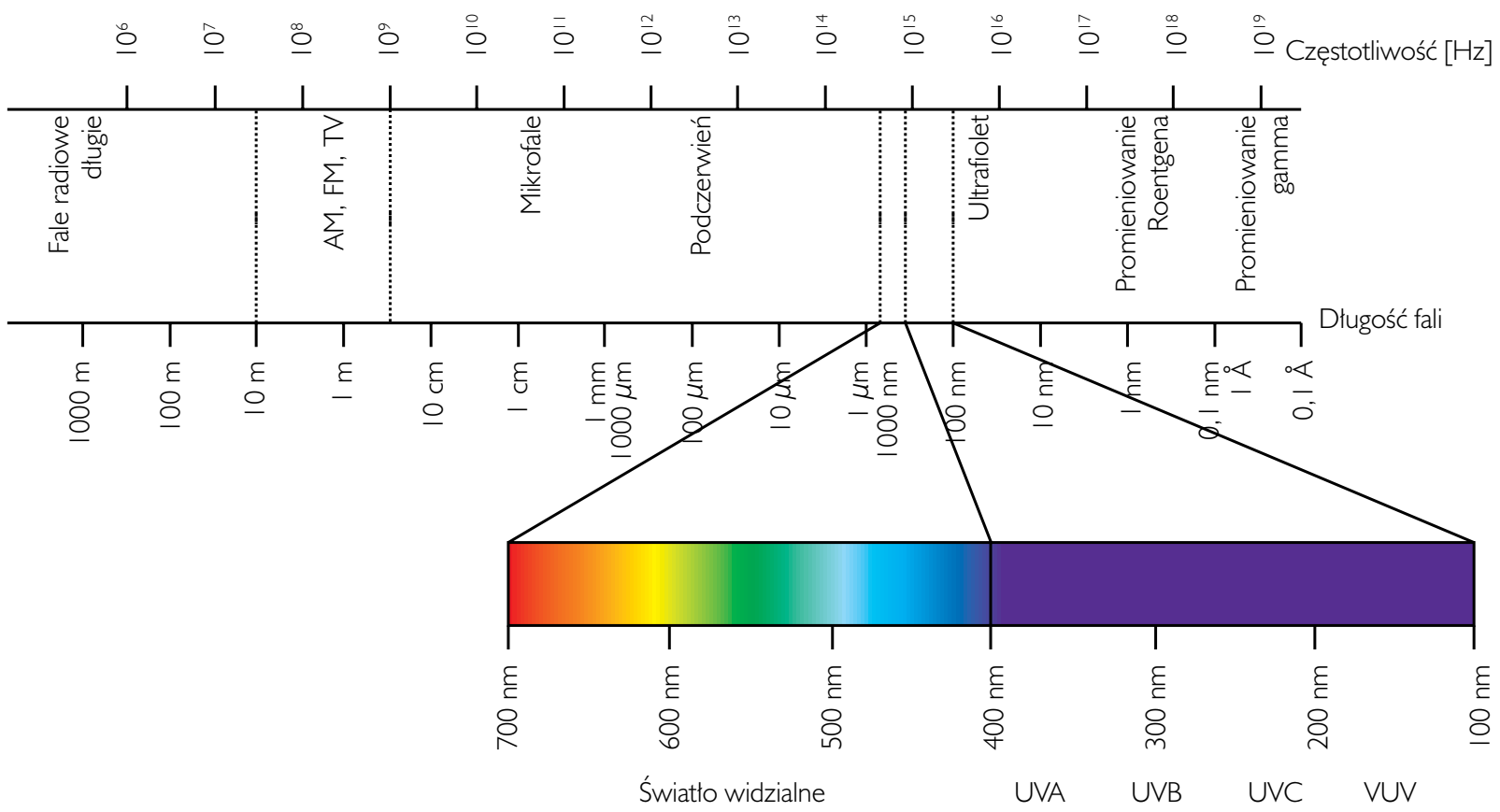

Rycina I. Widmo elektromagnetyczne

Phototherapy and photochemotherapy nowadays use equipment emitting radiation at the following lengths: UVB 311, UVB 313, UVB 308, UVA $320-400 \mathrm{~nm}$ with a beep at $365 \mathrm{~nm}$ and $340-400 \mathrm{~nm}$ UVA1. In Poland, the most commonly used radiation is UVB 311 and UVA $320-400 \mathrm{~mm}$ (mainly with psoralens) [2]. światło w zakresie pasm widzialnych: fiolet, niebieski, zielony, żółty, czerwony, głęboka czerwień, podczerwień.

W fototerapii i fotochemoterapii wykorzystuje się obecnie aparaturę emitującą następujące długości promieniowania: UVB 311, UVB 313, UVB 308, UVA $320-400 \mathrm{~nm}$ z pikiem $365 \mathrm{~nm}$ i UVA1 o długości 340-400 nm. Najczęściej w Polsce stosowane jest pro- 
Table I. Types of phototherapy and photochemotherapy

\begin{tabular}{l}
\hline UVB-broad band - exposure to the entire range of UVB radiation ( $280-320 \mathrm{~nm}$ ) \\
\hline SUP - selective UVB phototherapy using radiation of wavelengths between 305 and $325 \mathrm{~nm}$ \\
\hline UVB-narrow band - the latest method involving the use of narrow-band UVB of wavelength $3 \mathrm{II} \mathrm{nm}$ \\
\hline Re-SUP - combined use of retinoids and UVB \\
\hline PUVA (psoralen ultraviolet A) - classic photochemotherapy using orally administered psoralens (8-metoxypsoralen or \\
5-metoxypsoralen), applied to sensitize the skin to the action of ultraviolet radiation (UV) I-2 hours prior to exposure to UVA \\
radiation (320-400 nm, peak exposure wavelength $365 \mathrm{~nm}$ ) \\
\hline PUVA-bath - localized application of psoralens in a bath \\
\hline PUVA-topical - psoralens applied directly on the skin in the form of external preparations \\
\hline Re-PUVA - combined use of retinoids and UVB 305-325 nm \\
\hline UVAI - exposure to UVA band spectrum of wavelengths between 340 and $400 \mathrm{~nm}$
\end{tabular}

Tabela I. Typy fototerapii i fotochemoterapii

\begin{tabular}{l}
\hline UVB-broad band - naświetlania całym zakresem promieniowania UVB (280-320 nm) \\
\hline SUP - selektywna fototerapia (selective UVB phototherapy) to stosowanie promieniowania o zakresie 305-325 nm \\
\hline UVB-narrow band - najnowsza metoda polegająca na stosowaniu wąskiego spektrum promieniowania UVB o zakresie 3I I nm \\
\hline Re-SUP - skojarzone stosowanie retinoidów i UVB 305-325 nm \\
\hline PUVA (psoralen ultraviolet A) - fotochemoterapia klasyczna z wykorzystaniem doustnych psoralenów (8-metoksypsoralen lub \\
5-metoksypsoralen) podawanych w celu uwrażliwienia skóry na działanie promieni ultrafioletowych (UV) I-2 godziny przed \\
naświetlaniem promieniowaniem UVA (320-400 nm, szczyt naświetlania 365 nm) \\
\hline PUVA-bath - psoraleny podawane są miejscowo podczas kąpieli \\
\hline PUVA-topical - psoraleny podawane są bezpośrednio na skórę w postaci preparatów zewnętrznych \\
\hline Re-PUVA - skojarzone stosowanie retinoidów i UVB 305-325 nm \\
\hline UVAI - naświetlania spektrum pasma UVA o zakresie 340-400 nm
\end{tabular}

Photochemotherapy is a form of treatment by light, combining the use of ultraviolet and special chemical substances acting as photosensitizers (in a photochemical rather than photoallergic process), i.e. substances that heighten skin sensitivity to ultraviolet (mainly UVA). These substances are classified as psoralens. The term PUVA was originated in 1974 by Parrish et al. in a publication assessing the results of psoriasis treatment with orally administered 8-methoxypsoralen (8-MOP) and whole-body exposure to long-wave UVA radiation $[3,4]$ (table 1).

\section{PHOTOTYPE CLASSIFICATION}

The Fitzpatrick phototype scale is a clinically useful tool for assessing the response to UV. There are six phototypes (I-VI). The lower the phototype, the higher the individual skin sensitivity to UV and predisposition to burns.

\section{LIGHT TESTS}

Light tests involve the assessment of erythematous skin lesions presenting as a result of controlled doses of sunlight or visible sunlight within specific wavelength bands. Light tests may be used on patients as standard procedure preparatory to phototherapy mieniowanie UVB 311 i UVA 320-400mm (głównie z psoralenami) [2].

Fotochemoterapia to łączona forma leczenia światłem ultrafioletowym oraz specjalnymi substancjami chemicznymi będącymi fotouczulaczami (w mechanizmie fotochemicznym, a nie fotoalergicznym), czyli substancjami zwiększającymi wrażliwość skóry na ultrafiolet (głównie UVA). Substancje te należą do psoralenów. Termin PUVA został wprowadzony w 1974 roku przez Parrisha i wsp. w pracy oceniającej wyniki leczenia łuszczycy za pomocą podawanego doustnie 8-metoksypsoralenu (8-MOP) i naświetlań całego ciała długimi promieniami UVA [3, 4] (tab. 1).

\section{KLASYFIKACJA FOTOTYPÓW}

Fototyp skóry w skali wg Fitzpatricka jest przydatnym klinicznie narzędziem oceniającym reakcję na promieniowanie ultrafioletowe. Wyróżnia się sześć fototypów (I-VI). Im niższy jest fototyp, tym większa indywidualna wrażliwość skóry na promieniowanie UV i predyspozycja do oparzeń.

\section{PRÓBY ŚWIETLNE}

Próby świetlne polegają na ocenie zmian rumieniowych powstających na skórze pod wpływem kon- 
treatments, in order to determine the initial dose and rule out oversensitivity to any specific wavelength band [5].

\section{MINIMAL ERYTHEMA AND PHOTOXICAL DOSES}

Minimal erythema dose (MED) - the smallest quantity of radiation energy expressed in $\mathrm{J} / \mathrm{cm}^{2}$ causing regular skin erythema visible in the exposed site within 24 hours after exposure. This test is applied on dorsal skin or - preferably - on normally clothed places on the body, such as the buttocks, by exposing six skin sites, each sized $1.5 \times 1.5 \mathrm{~cm}$ to increasing doses of UVB radiation.

Minimal phototoxic dose (MPD) - determines the lowest threshold of UVA radiation combined with a strictly defined dose of photosensitizer (e.g. $0.6 \mathrm{mg} / \mathrm{kg} 8$-MOP by mouth) in order to produce an erythema after 48 hours and pigmentation after 72 hours.

\section{THE USE OF UVB IN DERMATOLOGY}

\section{UVB phototherapy}

Exposures take place 3-5 times weekly. Protective equipment should be provided for the eyes, scrotum and face if lesions do not present there.

The optimum initial dosage is $80 \%$ MED. The dosage can be increased with every single, every second or every third exposure by $15-30 \%$ provided that no signs of erythema appear. When erythema is present, the dosage should not be increased and kept at the sub-erythematous level (i.e. such that does not cause erythema).

\section{Narrow-band UVB 31I or 313}

Phototherapy by narrow-band UVB (TL-01 or NBUVB) came into widespread use in the 1980s and it is now the most common method of phototherapy [6].

It has been shown, in concurrence with the literature, that exposure to NB-UVB twice weekly leads to remission of skin lesions within 20 weeks in $63-75 \%$ of patients suffering from psoriasis. The initial improvement usually appears within the first 2 weeks, with 1520 treatments needed to induce the onset of remission. Lasting improvement holds for a period of a year in up to $38 \%$ of patients [7]. Based on data drawn from the literature, NB-UVB therapy allows PASI 75 improvements in $62 \%$ of sufferers [8]. Research conducted over the course of 38 years has proved that NB-UVB is superior to BB-UVB (broad-band UVB), as the former method produces better therapeutic results and causes psoriatic lesions to subside more rapidly [7].

Depending on the type of skin, the treatment should be dosed initially at $0.2-0.32 \mathrm{~J} / \mathrm{cm}^{2}$, with in- trolowanych dawek promieniowania słonecznego lub poszczególnych pasm widma tego promieniowania. Próby świetlne powinny być standardową procedurą wykonywaną u pacjentów przygotowywanych do zabiegów fototerapii w celu określenia początkowej dawki i wykluczenia ewentualnej nadwrażliwości na dany zakres widma słonecznego [5].

\section{MINIMALNA DAWKA RUMENIOWA I FOTOTOKSYCZNA}

Minimalna dawka rumieniowa (minimal erythema dose - MED) to najmniejsza ilość energii danego promieniowania wyrażona $\mathrm{w} \mathrm{J} / \mathrm{cm}^{2}$, która powoduje wystąpienie na skórze równomiernego rumienia widocznego w całym naświetlonym polu po 24 godzinach. Badanie wykonuje się na skórze pleców lub lepiej na skórze osłoniętej, np. pośladków, naświetlając 6 pól skórnych o wymiarach 1,5 × 1,5 cm wzrastającymi dawkami badanego promieniowania UVB.

Minimalna dawka fototoksyczna (minimal phototoxic dose - MPD) określa najmniejszą wartość promieniowania UVA w połączeniu ze ściśle zdefiniowaną dawką środka fotouczulającego (np. 0,6 mg/kg 8-MOP doustnie), która wywołuje po 48 godzinach rumień, a po 72 godzinach przebarwienie.

\section{ZASTOSOWANIE UVB W DERMATOLOGII}

\section{Fototerapia UVB}

Naświetlania prowadzi się 3-5 razy w tygodniu. W czasie naświetlania obowiązuje ochrona oczu i moszny oraz ochrona twarzy, jeżeli zmiany chorobowe nie dotyczą tej powierzchni.

Dawka początkowa to optymalnie $80 \%$ MED. Dawkę można zwiększać o 15-30\% przy każdym naświetlaniu lub co drugie albo nawet co trzecie naświetlanie, jeżeli nie wystąpi rumień. Po uzyskaniu rumienia dawki się nie zwiększa i kontynuuje się naświetlanie dawką podrumieniową (czyli największą, która jeszcze nie wywołuje rumienia).

\section{Wąskopasmowe UVB 3 I I lub 3 I 3}

Fototerapia wąskopasmowym UVB (TL-01 lub NB-UVB) została wprowadzona do użytku w latach 80. XX wieku. Obecnie jest najczęściej stosowaną metodą światłolecznictwa [6].

Zgodnie $\mathrm{z}$ piśmiennictwem stosowanie naświetlań NB-UVB 2 razy w tygodniu powoduje wystąpienie remisji zmian skórnych w czasie 20 tygodni u 63-75\% chorych na łuszczycę. Początkowa poprawa następuje zazwyczaj w ciągu 2 tygodni, średnio 15-20 zabiegów indukuje remisję, a stan poprawy utrzymuje się przez rok nawet u 38\% pacjentów [7]. Według danych z piśmien- 
Table 2. Contraindications for UVB therapy

\begin{tabular}{ll} 
Absolute & Relative \\
- Prior history of arsenic treatment & - Patient age under 8 \\
- After exposure to ionizing radiation & - Diabetes \\
- Epilepsy & - Immunological deficiency \\
- History or concurrent skin cancer & - Arterial hypertension \\
- Severe cardiovascular diseases & - Cyclosporine treatment \\
- Diseases associated with UV hypersensitivity (including genetic & - Other photosensitizing medications, such as certain antibiotics \\
factors) & (doxycycline, ciprofloxacin, sulphonamides), NSAIDs \\
- Claustrophobia (phototherapy cabins only) & (ibuprofen, ketoprofen, celecoxib), diuretics (furosemide, \\
- von Zumbusch pustular psoriasis & hydrochlorothiazide), statins, itraconazole and others \\
\hline
\end{tabular}

Tabela 2. Przeciwwskazania do fototerapii UVB

\begin{tabular}{ll} 
Bezwzględne & Względne \\
- Leczenie arsenem w wywiadzie & - Wiek pacjenta poniżej 8. roku życia \\
- Leczenie promieniami jonizującymi w wywiadzie & - Cukrzyca \\
- Padaczka & - Niedobory odpornościowe \\
- Istniejące lub przebyte nowotwory złośliwe skóry & - Nadciśnienie tętnicze \\
- Ciężkie choroby układu sercowo-naczyniowego & • Leczenie cyklosporyną \\
- Choroby przebiegające z nadwrażliwością na promienie UV & • Zażywanie innych leków fotouwrażliwiających, takich jak \\
- Klaustrofobia (dotyczy kabin) & niektóre antybiotyki (doksycyklina, ciprofloksacyna, sulfonamidy), \\
- Łuszczyca krostkowa typu von Zumbusch & niesteroidowe leki przeciwzapalne (ibuprofen, ketoprofen, \\
& celekoksyb), diuretyki (furosemid, hydrochlorotiazyd), statyny, \\
\hline
\end{tabular}

crements by $0.03-0.05 \mathrm{~J} / \mathrm{cm}^{2}$ in every third exposure. Protective equipment should be provided for the eyes and male reproductive organs if these areas are not affected by lesions.

PTD experts are divided on the question of supportive treatment, with some of them maintaining that it is not desirable in the case of psoriasis and mycosis fungoides, as there is no proof that this protects against relapses of the illness. The indications for UVB and UVB-NB therapy have been listed in table 8 [9-11].

\section{Errors in phototerapy}

The most common errors occuring in association with phototherapy are:

1. Radiation underdosage per single exposure (usually due to caution and difficult patient attitude). Solution: clarify in the first patient interview that this type of therapy involves a risk of slight erythema so that the patient can be mentally prepared for it rather than feel mistreated. Lower doses applied over longer cycles are not only therapeutically ineffective, but also unnecessarily increase overall exposure dosage, leading to an elevated risk of cancer.

2. Exposure too infrequent, e.g. twice a week higher frequency of exposure allows lessening dosage and thereby reducing overall dosage and the risk of complications such as skin cancer.

3. Inexperienced doctors ask distributors of phototherapy equipment for specific treatment schedules; no such schedules exist, nor should they be provided or nictwa terapia NB-UVB pozwala na uzyskanie poprawy rzędu PASI 75 u 62\% chorych [8]. W ciągu 38 lat wykazano przewage NB-UVB nad BB-UVB (broad-band UVB), ponieważ stosowanie wąskopasmowego UVB przynosiło lepsze wyniki leczenia i szybsze ustąpienie zmian łuszczycowych [7].

Dawka początkowa w zależności od typu skóry powinna wynosić $0,2-0,32 \mathrm{~J} / \mathrm{cm}^{2}$, a następnie powinna być zwiększana o 0,03-0,05 J/ $\mathrm{cm}^{2}$ co trzecie naświetlanie. Obowiązuje ochrona oczu i męskich narządów płciowych oraz twarzy, jeżeli nie trzeba jej naświetlać ze względu na zmiany chorobowe.

Problematyczne jest leczenie podtrzymujące, dlatego grupa ekspertów PTD stoi na stanowisku, że leczenie podtrzymujące łuszczycy i ziarniniaka grzybiastego jest niewskazane, ponieważ nie ma dowodów, aby taka praktyka zapobiegała nawrotom choroby. Wskazania do fototerapii UVB i UVB-NB podano w tabeli 8 [9-11].

\section{Błędy w stosowaniu fototerapii}

Poniżej przedstawiono najczęstsze błędy popełniane przez osoby stosujące fototerapię.

1. Stosowanie zbyt niskich pojedynczych dawek promieniowania (zazwyczaj z ostrożności). Rozwiązanie: $w$ czasie pierwszej rozmowy $\mathrm{z}$ pacjentem należy poinformować go, że z prowadzeniem tego rodzaju terapii wiąże się występowanie lekkiego rumienia i pacjent po każdym naświetlaniu powinien tego rumienia oczekiwać i nie uważać, że jest to błąd w zastosowanej dawce. Stosowanie dłuższych cykli, 
recommended by manufacturers (training provided by doctors experienced in phototherapy is necessary).

4. Some manufacturers provide phototherapy schedules stating that it is absolutely necessary to comply with the indicated doses (time periods). If any doses are stated, they should only be for reference to make clear whether the units to be applied are centimal, decimal or full $\mathrm{J} / \mathrm{cm}^{2}$ depending on the type of radiation spectrum. Exact dosage and dosage increments should be worked out individually or advice should be sought from mentors with expertise in the field, as each patient is different and reactions may vary depending on UV dosage applied.

There is also a mistaken notion of UVB $311 \mathrm{~nm}$ superior effectiveness for all indications. Both UVB-311 $\mathrm{nm}$ and PUVA have their advantages, so they should be used jointly. It would be good for each phototherapeutic centre to have the capability to provide both kinds of treatment [12].

\section{PHOTOCHEMOTHERAPY BY PUVA}

\section{The mechanism of operation}

Inhibition of excessive cell proliferation

Photochemotherapy (PUVA) is a method involving the combined use of psoralen and long-wave UV (UVA), which have a cumulative therapeutic effect [10]. A psoralen molecule embeds itself between complementary chains of two-strand DNA; next, UVA radiation absorbs the photon, leading to the binding of the thymine base, with subsequent photon absorption causing further thymine bindings and the formation of cross-bonds on neighbouring DNA strands. This is how pyrimidine dimers are formed. The presence of DNA-psoralen crossbonds inhibits DNA replication and stops the cell cycle [13].

\section{Stimulation of proteolytic enzymes}

UVA penetrates into the true skin (dermis), stimulating the production of metalloproteinases, mainly that of collagenase 1, resulting in collagen degradation. This mechanism is used mainly in the treatment of morphea $[14,15]$.

\section{Immunoregulatory mechanisms}

PUVA induces T-helper cell apoptosis as a result of singlet oxygen induction [16]. This mechanism is crucial for the treatment of atopic dermatitis (AD) and cutaneous T-cell lymphomas. Moreover, it has been shown that the expression of cytokines related to Th2, such as IL-5, IL-13 and IL-31 is suppressed $[17,18]$. ale mniejszych dawek pojedynczych nie daje oczekiwanych wyników terapeutycznych, a jednocześnie zwiększa niepotrzebnie dawkę skumulowaną, która długofalowo wpływa na ryzyko wystąpienia zmian nowotworowych.

2. Zbyt mała częstość naświetlań, np. 2 razy w tygodniu. Częstsze stosowanie naświetlań pozwala na zmniejszenie dawek, a przez to redukcję dawki skumulowanej i ryzyka wystąpienia odległych powikłań w postaci nowotworów skóry.

3. Wymaganie przez placówki medyczne konkretnych planów naświetlań od dystrybutorów urządzeń. Takich planów nie ma i producenci nie powinni ich sugerować ani udostępniać (należy korzystać z literatury medycznej i kursów prowadzonych przez lekarzy doświadczonych w fototerapii).

4. Podawanie przez niektórych producentów planu naświetlań z adnotacją o konieczności bezwzględnego przestrzegania podanych dawek (czasu). Jeżeli podawane są jakieś dawki, to powinny być to tylko dawki kierunkowe, wskazujące, czy stosujemy setne, dziesiętne czy pełne $\mathrm{J} / \mathrm{cm}^{2}$ - w zależności od rodzaju spektrum promieniowania. Dokładne dawki i ich wzrost należy wypracować samemu lub pozyskać je od ekspertów posiadających duże doświadczenie, gdyż każdy pacjent może inaczej zareagować na daną dawkę UV.

Istnieje również błędne przekonanie o większej skuteczności promieniowania UVB $311 \mathrm{~nm}$ we wszystkich wskazaniach. W rzeczywistości są wskazania do stosowania UVB $311 \mathrm{~nm}$, ale są też wskazania do stosowania PUVA i należy korzystać z obu rodzajów promieniowania. Byłoby dobrze, gdyby każdy ośrodek prowadzący fototerapię dysponował obiema metodami [12].

\section{FOTOCHEMOTERAPIA PUVA}

\section{Mechanizm działania}

\section{Hamowanie nadmiernej proliferacji komórek}

Fotochemoterapia (PUVA) jest metodą polegającą na skojarzonym stosowaniu psoralenu i długofalowego promieniowania UV (UVA), których łączne działanie wywołuje efekt leczniczy [10]. Cząsteczka psoralenu wbudowuje się pomiędzy komplementarne łańcuchy dwuniciowego DNA, po czym pod wpływem promieniowania UVA foton ulega absorpcji, następuje związanie zasady tyminowej, a absorpcja kolejnego fotonu powoduje związanie kolejnej zasady tyminowej i powstanie wiązań krzyżowych na sąsiadujących niciach DNA. Tak powstają dimery pirymidynowe. Obecność wiązań krzyżowych DNA-psoralen hamuje replikację DNA i powoduje zatrzymanie cyklu komórkowego [13]. 


\section{Immunosuppression/immunomodulation}

UVB is less immunosuppressive than PUVA. It has long been known that PUVA and UVB applied in succession lead to a drop in the epidermic Langerhaus count and a deterioration of antigen presentation. This also results in elevated tolerance to contact allergens [19]. Tests have also found elevated levels of secretion of IL-10 which displays immunosuppressive action through the inhibition of IFN- $\gamma$ and elevated levels of production of $\alpha-\mathrm{MSH}$. This inhibits the production of strongly inflammatory TNF- $\alpha$ cytokines while stimulating IL-10 [20]. UV also has the effect of boosting E2 prostaglandin production, which inhibits antigen presentation and Th1 activation [21] Lastly, UV stimulates the formation of cis-procaine acid which enables immunomodulatory action and serves as a natural sun screen.

\section{Summary}

The effects of PUVA include the loss of ability for replication, transcription and translation, inhibition of elevated epidermal mitotic activity, suppression of production of cytokines, reduction of Langerhans cell count and the number of circulating lymphocytes, more frequent exchanges between sister chromatids and genetic mutations [13].

\section{PHOTOCHEMOTHERAPY - EQUIPMENT AND APPARATUS}

To ensure safety and comfort for both patients and personnel, phototherapy units (cabins) intended for commercial use should strictly comply with the following requirements:

1) a minimum of 26-28 illuminators - configured to emit UVA or UVB $311 \mathrm{~nm}$ radiation or UVA/UVB$311 \mathrm{~nm}$ combination illuminators whose number ensures adequate radiation intensity (density) to reduce exposure times to levels acceptable to patients;

2) dosimetry, meaning continuous measurement of radiation intensity (density) affecting the patient during exposure, in order to ensure operation independent of the unit's wear and tear, and provide dosage each time precisely as per doctor's recommendations. Wall-mounted units are now also equipped with dosimetry systems;

3) capability to apply doses in $\mathrm{J} / \mathrm{cm}^{2}$. Only doses stated in $\mathrm{J} / \mathrm{cm}^{2}$ allow exchanging precise dosage information between doctors; stating doses in minutes or seconds is device-specific and cannot be reliably used with different devices without the risk of burning the patient; time is a secondary factor and dependent on radiation intensity determined by the number and quality of illuminators operating within a given spectrum;

\section{Stymulacja enzymów proteolitycznych}

UVA przenika do skóry właściwej, gdzie powoduje wzrost produkcji metaloproteinaz, głównie kolagenazy 1, co prowadzi do degradacji kolagenu. Ten mechanizm wykorzystuje się głównie w leczeniu morphea $[14,15]$.

\section{Mechanizmy immunoregulujące}

PUVA indukuje apoptozę komórek T-helper, co jest pierwotnie spowodowane wyindukowaniem tlenu singletowego [16]. Ten mechanizm jest istotny w leczeniu atopowego zapalenia skóry (AZS) i skórnych chłoniaków T komórkowych. Wykazano ponadto, że ekspresja cytokin związanych z Th2, takich jak IL-5, IL-13 i IL-31, ulega supresji $[17,18]$.

\section{Immunosupresja/immunomodulacja}

UVB w mniejszym stopniu niż PUVA działa immunosupresyjne. Już dawno zaobserwowano, że pod wpływem PUVA, a następnie pod wpływem UVB dochodzi do redukcji liczby komórek Langerhansa w naskórku i pogorszenia funkcji prezentacji antygenu. Skutkuje to zwiększeniem tolerancji na alergeny kontaktowe [19]. Stwierdzono ponadto wzrost wydzielania IL-10, która działa immunosupresyjnie przez hamowanie wytwarzania IFN- $\gamma$, wzrost wydzielania $\alpha-\mathrm{MSH}$, który hamuje produkcję silnie prozapalnych cytokin TNF- $\alpha$ i stymuluje IL-10 [20]. Pod wpływem UV następuje wzrost produkcji prostaglandyny E2, co hamuje prezentację antygenów i aktywację Th1 [21]. Ponadto UV stymuluje powstawanie kwasu cis-prokainowego, który działa immunomodulująco i stanowi naturalną osłonę przeciwsłoneczną.

\section{Podsumowanie}

Pod wpływem PUVA następują: utrata zdolności do replikacji, transkrypcji i translacji, zahamowanie zwiększonej aktywności mitotycznej naskórka, supresja produkcji cytokin, zmniejszenie liczby komórek Langerhansa i krążących limfocytów Th, zwiększenie częstości wymiany pomiędzy siostrzanymi chromatydami oraz mutacje genowe [13].

\section{FOTOCHEMOTERAPIA - WYPOSAŻENIE I APARATURA}

Profesjonalne urządzenia do fototerapii, aby zapewnić bezpieczeństwo i komfort zarówno pacjentom, jak i personelowi, powinny spełniać następujące wymogi:

1) kabiny powinny posiadać co najmniej 26-28 promienników - w konfiguracji mono UVA lub UVB $311 \mathrm{~nm}$ oraz kombi promienniki UVA i UVB $311 \mathrm{~nm}$ w liczbie zapewniającej odpowiednie natężenie (gę- 
Table 3. Contraindications for photochemotherapy

\begin{tabular}{ll} 
Absolute & Relative \\
\hline - Pregnancy and breastfeeding & - Patient age under I2 \\
- History of arsenic treatment & - Diabetes \\
- Prior exposure to ionizing radiation & - Immunological deficiency \\
- Epilepsy & - Arterial hypertension \\
- History or concurrent skin cancer & - Cyclosporine treatment \\
- Severe cardiovascular diseases & - Other photosensitizing medications, such as certain antibiotics \\
- Severe hepatic or renal insufficiency & (doxycycline, ciprofloxacin, sulphonamides), NSAIDs \\
- Cataract & (ibuprofen, ketoprofen, celecoxib), diuretics (furosemide, \\
- Diseases associated with UV hypersensitivity & hydrochlorothiazide), statins, itraconazole and many others \\
- Claustrophobia (in cabins only) & \\
- Pustular psoriaris, von Zumbusch type & \\
\hline
\end{tabular}

Tabela 3. Przeciwwskazania do fotochemoterapii

\begin{tabular}{ll} 
Bezwzględne & Względne \\
\hline - Ciąża i karmienie piersią & - Wiek pacjenta poniżej I2. roku życia \\
- Leczenie arsenem w wywiadzie & - Cukrzyca \\
- Leczenie promieniami jonizującymi w wywiadzie & - Niedobory odpornościowe \\
- Padaczka & - Nadciśnienie tętnicze \\
- Istniejące lub przebyte nowotwory złośliwe skóry & - Leczenie cyklosporyną \\
- Ciężkie choroby układu sercowo-naczyniowego & - Zażywanie innych leków fotouwrażliwiających, takich \\
- Ciężka niewydolność wątroby i nerek & jak niektóre antybiotyki (doksycyklina, ciprofloksacyna, \\
- Zaćma & sulfonamidy), niesteroidowe leki przeciwzapalne \\
- Choroby przebiegające z nadwrażliwością na promienie UV, & (ibuprofen, ketoprofen, celekoksyb), diuretyki (furosemid, \\
- W tym uwarunkowane genetycznie & hydrochlorotiazyd), statyny, itrakonazol i inne \\
- Kusztrofobia (w kabinach) & \\
\hline
\end{tabular}

4) equipped with an UV-filter sight glass to review the interior of the cabin and check up on the patient. The patient also feels safe and shows no claustrophobic behaviour, knowing that he/ she can look outside the cabin.

Indications, rare indications, indications for allergic diseases and cancer (cutaneous lymphoma) have been listed in table 8 [9-11].

\section{Ingestion and excretion of psoralens}

Psoralens are soluble in fats. Only 8-methoxyposralen (8-MOP) in liquid form in soft gelatine capsules is now available in Poland. Ninety-five percent of orally administered psoralens are absorbed in the digestive tract. Maximum concentration in the serum is achieved within 1-3 hours after administration. Psoralens are metabolized in the liver's endoplasmic reticulum through oxidation, carboxylation, hydrolysis and glucuronidation. Ninety percent is excreted by urine within 12 hours and the remaining $4-10 \%$ with gall [22].

\section{Dosage of orally administered psoralens and determination of UVA doses}

$8-\mathrm{MOP}$ is administered orally at $0.6-0.8 \mathrm{mg} / \mathrm{kg}$ of body weight once an hour prior to exposure. The best way to facilitate the choice of appropriate dosage are stość) promieniowania, aby czasy naświetlań były akceptowalne dla pacjentów;

2) być wyposażone w dozymetrię, tj. ciągły pomiar natężenia (gęstości) promieniowania w czasie naświetlania pacjenta, aby uniezależnić się od oceny zużycia promienników i zapewnić każdorazowo wyemitowanie dokładnie takiej dawki, jaką zalecił lekarz. Obecnie tzw. ścianki są również wyposażane $\mathrm{w}$ takie systemy dozymetrii;

3) zapewniać podawanie dawek $\mathrm{w} \mathrm{J} / \mathrm{cm}^{2}$ - tylko dawki wyrażone $w$ tych jednostkach umożliwiają przekazywanie informacji między lekarzami; podawanie dawek w minutach lub sekundach jest ściśle związane z danym urządzeniem i w przypadku ich przeniesienia na inne urządzenie można dojść np. do oparzenia pacjenta; czas jest rzeczą wtórną i zależy od natężenia promieniowania, a to jest zależne od liczby i jakości promienników danego spektrum;

4) być wyposażone w okienko z filtrem UV do zaglądania do wnętrza kabiny i monitorowania stanu pacjenta. Pacjent mający świadomość, że może spojrzeć na zewnątrz kabiny, czuje się pewniej i nie ma zaburzeń klaustrofobicznych.

Wskazania, rzadkie wskazania, wskazania w chorobach alergicznych i w nowotworach (chłoniakach) skóry przedstawiono $\mathrm{w}$ tabeli 8 [9-11]. 
erythema and phototoxic tests. When this is not possible, we can use skin phototype as a reference.

\section{Dosage of UVA in general photochemotherapy (oral PUVA)}

The initial dosage starts from $0.5-2 \mathrm{~J} / \mathrm{cm}^{2}$, as appropriate for a given phototype, followed by increments of $0.2-1 \mathrm{~J} / \mathrm{cm}^{2}$ every third exposure depending on the initial dosage. If MPD assessment is possible, exposure should start with 50-80\% MPD and increase in dosage by $15-30 \%$ every second or third exposure. Exposures should take place 3-4 times weekly (Monday-Wednesday-Friday or Monday-Tuesday-Thursday-Friday).

\section{Dosage of UVA in local photochemotherapy (local PUVA)}

Skin lesions should be treated with a solution of $0.1-0.15 \%$ 8-MOP for a duration of around 30 minutes, followed by exposure at $0.25 \mathrm{~J} / \mathrm{cm}^{2} \mathrm{UVA}$. Psoralen cream with identical concentration can be used.

\section{PUVA bath}

The patient should take a bath in a solution of $0.1 \mathrm{~g} / 1$ for a duration of 20 minutes $36-38^{\circ} \mathrm{C}$, followed by exposure to UVA radiation as per phototype and diagnosis $[9,23]$.

\section{GENERAL RECOMMENDATIONS}

Treatment should be shortened as much as possible to reduce the overall dosage of UVA through the use of combined therapy (steroids, dithranol locally or retinoids generally). Eye protection should be worn during PUVA treatments and when exposed to psoralens. This is applicable to patients after PUVA baths.

\section{SPECIAL INDICATIONS}

Protection should be used for male reproductive organs and as far as possible facial skin. In the case of chronic diseases, such as psoriasis, therapy should be applied alternately (e.g. RePUVA, PUVA alternating with methotrexate). The terapeutic methods should be individually selected to every patient.

\section{Photochemotherapy for mycosis fungoides and Sezary disease}

Due to extreme photosensitivity of the focal sites of pre-mycotic conditions and mycosis fungoides and infiltrated skin in a pre-clinical state, dosage of UVA should follow the recommendations for skin phototype 1. Radiation dosage should be increased slowly and cautiously. PUVA is a treatment method of choice in the early stages of mycosis fungoides.

\section{Wchłanianie i wydalanie psoralenów}

Psoraleny są rozpuszczalne w tłuszczach. Od kilku lat w Polsce dostępny jest tylko 8-metoksypsoralen (8-MOP) w postaci płynnej w miękkich kapsułkach żelatynowych. W przewodzie pokarmowym wchłania się 95\% przyjętych doustnie psoralenów. Maksymalne stężenie w surowicy osiąga się 1-3 godzin po przyjęciu leku. Metabolizm odbywa się w siateczce śródplazmatycznej wątroby na drodze oksydacji, karboksylacji, hydrolizy i glukuronizacji. W ciągu 12 godzin $90 \%$ wydala się z moczem, a 4-10\% z żółcią [22].

\section{Dawkowanie psoralenów doustnych i ustalanie dawki UVA}

8-MOP podawany jest doustnie w dawce $0,6-0,8 \mathrm{mg}$ / kg m.c. 1 godzinę przed naświetlaniem. Najlepszą metodą ułatwiającą wybór odpowiedniej dawki są próby rumieniowe i fototoksyczne. Gdy nie można ich wykonać, należy sugerować się fototypem skóry.

\section{Dawkowanie UVA w fotochemoterapii ogólnej (oral PUVA)}

W zależności od fototypu rozpoczyna się od dawki 0,5-2 J/ $\mathrm{cm}^{2}$, następnie co trzecie naświetlanie zwiększa się dawkę o 0,2-1 J/ cm², w zależności od dawki inicjującej. Jeżeli można oznaczyć MPD, to zaczyna się naświetlanie od 50-80\% MPD, dawkę zwiększa się o 15-30\% co drugie, trzecie naświetlanie. Naświetlania prowadzi się 3-4 razy w tygodniu (poniedziałek-środa-piątek lub poniedziałekwtorek-czwartek-piątek).

\section{Dawkowanie UVA w fotochemoterapii miejsco- wej (local PUVA)}

Na zmiany skórne aplikuje się $0,1-0,15 \%$ roztwór 8-MOP na około 30 minut, a następnie naświetla się dawką 0,25 J/ $\mathrm{cm}^{2}$ UVA. Można stosować krem z psoralenami o tym samym stężeniu.

\section{Balneo-PUVA (PUVA bath)}

Pacjent kąpie się w roztworze psolarenów o stężeniu $0,1 \mathrm{~g} / 1$ przez 20 minut $\mathrm{w}$ temperaturze $36-38^{\circ} \mathrm{C}$, a następnie naświetla się $\mathrm{w}$ kabinie promieniami UVA zgodnie z fototypem i rozpoznaniem $[9,23]$.

\section{ZALECENIA OGÓLNE}

Należy maksymalnie skracać leczenie w celu ograniczenia łącznej dawki UVA poprzez stosowanie terapii skojarzonej (glikokortykosteroidy, cygnolina stosowana miejscowo lub retinoidy ogólnie). Konieczna jest ochrona narządu wzroku podczas zabiegów PUVA, a także 
Table 4. Adverse effects of photochemotherapy [25-28]

\begin{tabular}{ll} 
Frequent & Rare \\
\hline - Nausea, vomiting, diarrhoea & - Blisters, pemphigoid \\
- Abdominal pain & - Hypertrichosis \\
- Headache and vertigo & - Neuralgia \\
- Fatigue & - Diffuse granuloma annulare \\
- Oedema & - Nail lesions (photo-onycholysis, melanonychia) \\
- Itch & - Temporary increase in aminotransferase activity \\
- Tachycardia & - Trombocytopenia \\
- Koebner phenomenon & - Impaired intestinal calcium absorption \\
& - UV-induced onset of lupus erythematosus with antinuclear antibodies \\
\hline
\end{tabular}

Tabela 4. Objawy niepożądane fotochemoterapii [25-28]

\begin{tabular}{ll} 
Najczęstsze & Rzadkie \\
\hline - Nudności, wymioty, biegunka & - Pęcherze, pemfigoid \\
- Bóle brzucha & - Nadmierne owłosienie \\
- Bóle i zawroty głowy & - Neuralgia \\
- Uczucie zmęczenia & - Wysiew ziarniniaka obrączkowatego \\
- Obrzęki & - Zmiany paznokciowe (fotoonycholiza, melanonychia) \\
- Świąd skóry & - Przejściowy wzrost aktywności transaminaz \\
- Tachykardia & - Trombocytopenia \\
- Objaw Koebnera & - Zaburzenia wchłaniania wapnia \\
& - Prowokacja zmian skórnych typu tocznia rumieniowatego z obecnością \\
& przeciwciał przeciwjądrowych
\end{tabular}

Table 5. Potential long-term consequences of long-lasting photochemotherapy [29]

\begin{tabular}{l}
\hline Ocular abnormalities (cataract) \\
\hline Skin photodamage \\
\hline Photoaging \\
\hline Immunological abnormalities \\
\hline Cancerogenesis \\
\hline
\end{tabular}

Treatment should be continued until histological remission. Supporting treatment is a question of debate. Survival period is 5 years and comparable with RTG therapy and local nitrogranulogene $[17,24]$.

\section{ADVERSE EFFECTS}

Adverse effects have been listed in Tables 4 and 5 and organized according to frequency of occurrence [25-29].

\section{THE USE OF UVAI IN DERMATOLOGY}

The use of long-wave 340-400 nm ultraviolet - UVA1 represents a relatively new form of phototherapy. Lamps emitting UVA1 radiation were designed in the 1980s. This marked the beginning of research on the biological effect of UVA1 radiation on animal and human skin, resulting in the first attempts to apply this form of phototherapy in
Tabela 5. Potencjalne odległe następstwa przewlekłej fotochemoterapii

\begin{tabular}{l}
\hline Uszkodzenie narządu wzroku (zaćma) \\
\hline Przewlekłe świetlne uszkodzenie skóry \\
\hline Posłoneczne starzenie skóry - photoaging \\
\hline Zaburzenia immunologiczne \\
\hline Kancerogeneza
\end{tabular}

w dniu zażycia psoralenów, dotyczy to także pacjentów po kąpielach PUVA.

\section{ZALECENIA SZCZEGÓLNE}

Obowiązuje ochrona narządów płciowych u mężczyzn oraz skóry twarzy, jeśli jest to możliwe. W przypadku chorób przewlekłych, takich jak łuszczyca, należy stosować terapię naprzemienną (np. RePUVA, PUVA na zmianę z metotreksatem). Właściwy dobór metody dla każdego pacjenta jest niezmiernie ważny dla osiągnięcia pożądanych wyników w odpowiednim czasie.

\section{Fotochemoterapia w ziarniniaku grzybiastym i zespole Sezary'ego}

Ze względu na wybitną fotowrażliwość ognisk stanów premykotycznych i ziarniniaka grzybiastego oraz skóry z naciekami w stanie przedklinicznym dawkowanie UVA powinno być zalecane jak w fototypie I skóry. Dawki promieniowania należy zwięk- 
the diagnostics and treatment of skin diseases. Initially, it proved to be helpful in diagnostics, e.g. in provoking skin lesions in polymorphous light eruptions. No satisfactory results were achieved in the treatment of vitiligo and acne. More publications did not appear until after 1992 when Krutmann et al. reported very good results in the treatment of AD with the use of high doses of UVA1 [30]. Two types of sources of UVA1 light are available at present: fluorescent lamps generating low and medium doses of UVA1, which are small, portable, cheap and more readily available as well as high-pressure metal haloid lamps delivering higher doses but more expensive and requiring adaptations of space and the installation of cooling systems [31].

\section{Principle of operation}

UVA1 radiation penetrates deeper into the true skin, reaching the reticular layer, and is characterized by immunomodulatory properties. This method's success in the treatment of AD and mycosis fungoides is probably attributable to the ability to induce the T lymphocyte apoptosis [17, 18, 32]. It also reduces Langerhans cell count as well as the number of mastocytes and basophils and pro-inflammatory cytokines post-exposure in patients suffering from atopic dermatitis or mycosis fungoides. Recently published research confirms that UVA1 phototherapy both in vitro and in vivo may inhibit calcineurin; by oxidation of Met and Cys moieties, it causes conformation changes in the protein, acting in much the same way as cyclosporine or tacrolimus [33]. Cancerous T lymphocytes of mycosis fungoides, rich in caspases, seem to be especially sensitive to UVA1. On the other hand, UVA1 phototherapy is a method acting upon various stages of the disease process in morphea [24,34]. It has an inhibitory effect on the inflammation process by preventing the progress of the disease but also causes fibrosis that comes as its consequence. The proposed mechanism of operation is multi-directional, including immunomodulatory action thanks to the capability for apoptosis induction in $\mathrm{T}$ and B lymphocytes (including the so-called pre-programmed cell death, mediated by superoxide radical, a unique instance of early apoptosis that does not present following exposure to PUVA), its impact on the production of pro-inflammatory cytokines as well as the ability to induce fibroblasts to produce collagenase. This enzyme has been shown to be more expressive in sclerotic sites, correlating with a clinical improvement. UVA1 radiation may also impact on endothelic cells to promote neovascularization [35].

\section{Indications}

Considering the above mechanism of operation, any potential indications for treatment by szać ostrożnie i wolno. PUVA jest metodą z wyboru we wczesnych stadiach ziarniniaka grzybiastego. Leczenie powinno się prowadzić do uzyskania remisji histologicznej. Leczenie podtrzymujące jest dyskusyjne. Pięcioletnie przeżycie jest porównywalne z uzyskiwanym w wyniku terapii promieniami rentgenowskimi i miejscowym nitrogranulogenem [17, 24].

\section{OBJAWY NIEPOŻĄDANE}

Działania niepożądane podsumowano w tabelach 4 i 5 oraz uszeregowano według częstości występowania [25-29].

\section{ZASTOSOWANIE UVAI W DERMATOLOGII}

Zastosowanie długofalowego ultrafioletu w zakresie 340-400 nm - UVA1 jest stosunkowo nową formą fototerapii. Lampy emitujące promieniowanie UVA1 zostały skonstruowane już w latach 80. ubiegłego wieku. Rozpoczęto wówczas badania nad efektem biologicznym promieniowania UVA1 na skórę zwierząt doświadczalnych i ludzką, a następnie podjęto pierwsze próby zastosowania tego rodzaju fototerapii w diagnostyce i leczeniu chorób skóry. Początkowo okazało się ono pomocne w diagnostyce, między innymi w prowokacji zmian skórnych w wielopostaciowych osutkach świetlnych. Nie uzyskano natomiast zadowalających wyników w leczeniu bielactwa i trądziku. Więcej prac ukazało się dopiero po 1992 roku, gdy Krutmann i wsp. opublikowali bardzo dobre wyniki leczenia AZS z zastosowaniem wysokich dawek UVA1 [30]. Obecnie dostępne są dwa rodzaje źródeł UVA1: lampy fluorescencyjne generujące niskie i średnie dawki UVA1, małe i przenośne, tańsze i łatwiej dostępne oraz wysokociśnieniowe lampy metalowo-haloidowe, umożliwiające osiągnięcie dawek wysokich, jednak droższe oraz wymagające dostosowania pomieszczenia i instalacji systemów chłodzenia [31].

\section{Mechanizm działania}

Promieniowanie UVA1 przenika głęboko w obręb skóry właściwej, osiągając warstwę siateczkowatą, i charakteryzuje się właściwościami immunomodulującymi. Zdolność do indukcji apoptozy limfocytów T prawdopodobnie odpowiada za skuteczność tej metody w leczeniu AZS i ziarniniaka grzybiastego [17, 18, 32]. Po naświetlaniu u chorych na AZS i mastocytozę skórną zmniejsza się liczba komórek Langerhansa, komórek tucznych i bazofilów oraz licznych cytokin prozapalnych. Ostatnio ukazały się również badania potwierdzające zarówno in vitro, jak i in vivo, że fototerapia UVA1 może hamować kalcyneurynę - na drodze oksydacji reszt Met i Cys powoduje zmiany konformacyjne tego białka, dzia- 
Table 6. Doses and treatment patterns for UVAI [3, I6]

\begin{tabular}{lccc} 
Dose & Small $\left[\mathrm{J} / \mathrm{cm}^{2}\right]$ & Medium $\left[\mathrm{J} / \mathrm{cm}^{2}\right]$ & Large $\left[\mathrm{J} / \mathrm{cm}^{2}\right]$ \\
Single & $20-40$ & $40-80$ & $80-120$ \\
& $(10-20)$ & $(20-70)$ & $(70-130)$ \\
\hline Total & $<300$ & $300-975$ & $>975$ \\
\hline
\end{tabular}

UVA1 radiation can be classified, according to Krutmann, into four basic categories of diseases, including:

1) skin diseases dependent on T lymphocytes, inflammation diseases, including AD, mycosis fungoides and granuloma annulare;

2) skin diseases mediated by mastocytes, utricaria pigmentosa;

3) diseases accompanied by sclerosis, limited sclerosis, lichen sclerosus, chronic sclerodermoid graft versus host disease (cGvHD), scleromyxedema, scleroedema and other rare conditions, e.g. POEMS (polyneuropathy, organomegaly, endocrinopathy, monoclonal protein, skin changes) or NFD (nephrogenic fibrosing dermopathy).

4) phototherapy for HIV-positive patients as the safest method without impact on the virus replication level [11] (table 6).

Despite numerous research articles concerning UVA1 effectiveness in the treatment of various skin diseases, the majority of these reports are mainly open-ended research projects and study cases [36, 37]. Publications comparing the effects of UVA1 treatment with other standard or placebo-controlled methods are few. The length of treatment or doses are not clearly established, either. The norm is to use 20-30-40 exposures per treatment cycle, 2-5 times weekly.

\section{Safety}

Despite plentiful research, the mechanism of operation of UVA1 has not been clearly understood. The molecule absorbing the radiation, the so-called chromophore, remains unknown. In the case of UVB, the absorbent molecule is DNA. The impact of UVA on DNA is probably indirect in that it generates oxygen free radicals [38]. However, latest research has shown that DNA strands also undergo mutation under the influence of UVA1 radiation (emitted experimentally by a laser source). This includes mainly 8-hydroxy 2-deoxyguanosine $(8 \mathrm{OHdG})$ with unprov-

Table 7. Examples of possible combined treatments with phototherapy

\begin{tabular}{l}
\hline Glucocorticosteroids + UVB/PUVA \\
\hline Dithranol + UVB/PUVA \\
\hline Systemic retinoids + UVB/PUVA (Re-UVB, Re-PUVA) \\
\hline
\end{tabular}

Tabela 6. Stosowane dawki i schematy leczenia UVAI $[3,16]$

\begin{tabular}{lccc} 
Dawka & Mała [J/cm$\left.{ }^{2}\right]$ & Średnia [J/cm $\left.{ }^{2}\right]$ & Duża $\left[\mathrm{J} / \mathrm{cm}^{2}\right]$ \\
Pojedyncza & $20-40$ & $40-80$ & $80-120$ \\
& $(10-20)$ & $(20-70)$ & $(70-130)$ \\
\hline Sumaryczna & $<300$ & $300-975$ & $>975$ \\
\hline
\end{tabular}

łając podobnie jak cyklosporyna lub takrolimus [33]. Nowotworowe limfocyty T ziarniniaka grzybiastego, bogate w kaspazy, wydają się szczególnie wrażliwe na UVA1. Fototerapia UVA1 oddziałuje również na różne etapy procesu chorobowego w morphea [24, 34]. Hamuje proces zapalny, zapobiegając postępowi choroby, a także wpływa na włóknienie, które jest jego efektem. Proponowany mechanizm działania jest wielokierunkowy. Obejmuje immunomodulację wynikającą ze zdolności do indukcji apoptozy w dwóch mechanizmach - w obrębie limfocytów T i B (w tym unikalne zjawisko wczesnej apoptozy niewystępujące po naświetlaniach PUVA, tzw. pre-PCD (pre-programmed cell death), mediowane przez anionorodnik ponadtlenkowy), wpływ na produkcję cytokin prozapalnych, a także zdolność do indukowania produkcji kolagenazy przez fibroblasty. W ogniskach twardzinowych wykazano zwiększoną ekspresję tego enzymu, co korelowało z poprawą kliniczną. Promieniowanie UVA1 może również oddziaływać na komórki śródbłonka, promując neowaskularyzację [35].

\section{Wskazania}

W związku z powyższym mechanizmem działania potencjalne wskazania do leczenia promieniowaniem UVA1 obejmują wg Krutmanna i wsp. cztery podstawowe kategorie schorzeń:

1) choroby skóry zależne od limfocytów T, choroby o podłożu zapalnym, w tym AZS, ziarniniak grzybiasty, ziarniniak obrączkowaty;

2) choroby skóry mediowane przez mastocyty - pokrzywka barwnikowa;

3) choroby przebiegające ze stwardnieniami skóry: twardzina ograniczona, liszaj twardzinowy, twardzinopodobna postać przewlekłej choroby przeszczep przeciwko gospodarzowi (chronic sclerodermoid graft versus host disease - cGvHD), scleromyxedema, scleroedema, zespół POEMS (polyneuropathy, organomegaly, endocrinopathy, monoclonal protein, skin changes) lub nerkopochodna dermopatia włókniejąca (nephrogenic fibrosing dermopathy);

Tabela 7. Przykładowe możliwości leczenia skojarzonego z fototerapią

\begin{tabular}{l}
\hline Glikokortykosteroidy + UVB/PUVA \\
\hline Cygnolina + UVB/PUVA \\
\hline Retinoidy ogólnie + UVB/PUVA (Re-UVB, Re-PUVA) \\
\hline
\end{tabular}


en genotoxic properties and CPDs - cyclopirymidine dimers with C->T transition. However, it is emphasized throughout that the skin used for these experiments was grown artificially or extracted from mice and thus much thinner than human skin. Additionally, a single designation does not take into account restorative mechanisms such as apoptosis and others, e.g. induction of anti-inflammatory heme-1 (HO-1) oxygenase [39]. However, further research into the matter is necessary. The literature has hitherto provided three retrospective studies involving 423 patients who underwent from 4 to 116 treatments and did not suffer from any remote side-effects of UVA1 therapy, such as skin cancer [36, 37]. The literature describes two cases of Merkel cell cancer from patients exposed to UVA1, but they were subjected to prior photochemotherapy by PUVA and immunosuppressive medication [40]. It is now recommended, just as with PUVA, to administer no more than 200 treatments, complete a maximum of 2 cycles of treatment and provide the treatment to adults only [11].

\section{Summary}

UVA1 phototherapy is nowadays used to supplement standard methods of phototherapy, such as UVB and PUVA, and may be seen as an alternative in the case of some diseases. The chief and most promising indication for its use seems to be limited sclerosis and some sclerotic diseases. It is a supporting method in the treatment of AD in adults, particularly at times of aggravation of the disease. The method may be combined with external medicines, i.e. glicocorticosteroids or emollients. However, joint use should be avoided with tacrolimus or pimecrolimus or generally administered cyclosporine A. Average doses of UVA1 seem to be effective and free from side effects calling for the use of psoralens as in standard PUVA therapy. Also, the risk of phototoxicity is considerably lower. The downsides include high cost of equipment and availability limited to specialist centres possessing adequate machinery.

Combination of phototherapy and photochemotherapy is not recommended with: topically applied calcineurin inhibitors (with the exception of vitiligo) and generally applied methotrexate and immunosupressive biological medications.

It is prohibited to combine phototherapy and photochemotherapy with cyclosporine and azathioprine.

\section{PHOTOTHERAPY IN CHILDREN}

Phototherapy is a safe and effective treatment method for paediatric patients. It is used especially with children affected with psoriasis, AD, vitiligo and
4) fototerapia u pacjentów HIV-dodatnich jako metoda najbezpieczniejsza, niewpływająca na poziom replikacji wirusa [11] (tab. 6).

Pomimo dużej liczby prac na temat skuteczności UVA1 w leczeniu różnych schorzeń skóry większość doniesień stanowią badania otwarte i opisy przypadków [36, 37]. Nadal niewiele jest publikacji porównujących efekty leczenia UVA1 z efektami innych standardowych metod czy badań kontrolowanych placebo. Nie ustalono również dokładnie protokołów długości leczenia i wysokości dawek. Zazwyczaj stosuje się 20-40 naświetlań w cyklu leczenia, 2-5 razy w tygodniu.

\section{Bezpieczeństwo}

Mimo dość licznych badań mechanizm działania promieniowania UVA1 nie został do końca poznany. Nieznana jest cząsteczka pochłaniająca promieniowanie, tzW. chromofor. W przypadku UVB cząsteczką bezpośrednio absorbująca jest DNA. Wpływ UVA na DNA jest prawdopodobnie pośredni, poprzez generowanie tzw. wolnych rodników tlenowych [38]. Ostatnie badania wykazują jednak, że pod wpływem promieniowania UVA1 (eksperymentalnie emitowanego ze źródła laserowego) również dochodzi do powstania mutacji w obrębie nici DNA. Są to głównie: 8-hydroksy 2-deoksyguanozyna (8OHdG) o nieudowodnionych właściwościach genotoksycznych oraz dimery cyklopirymidynowe (cyclopirymidine dimers - CPDs) o typie tranzycji C->T. W dyskusji podkreśla się jednak, że w tych badaniach modelem jest hodowla skóry lub skóra myszy, znacznie cieńsza od ludzkiej. Dodatkowo pojedyncze oznaczenie nie uwzględnia udziału mechanizmów naprawczych, takich jak apoptoza, czy innych, np. indukcji oksygenazy hemu 1 (HO-1) o właściwościach przeciwzapalnych [39]. Niezbędne są dalsze badania w tym zakresie. Dotychczas $w$ piśmiennictwie ukazały się trzy badania retrospektywne obejmujące 423 pacjentów, którzy przeszli 4-116 zabiegów. Nie stwierdzono odległych objawów niepożądanych fototerapii UVA1, takich jak nowotwory skóry [36, 37]. W literaturze opisano dwa przypadki raka z komórek Merkla u pacjentów naświetlanych między innymi UVA1, jednak były to osoby wcześniej leczone fotochemoterapią PUVA i lekami immunosupresyjnymi [40]. Obecnie zaleca się, podobnie jak w przypadku PUVA, nieprzekraczanie 200 zabiegów, prowadzenie maksymalnie 2 cykli leczenia w roku oraz przestrzeganie zalecenia leczenia tylko osób dorosłych [11].

\section{Podsumowanie}

Obecnie naświetlanie UVA1 stanowi uzupełnienie standardowych metod fototerapii, takich jak UVB czy PUVA, i może być uznane za metodę alternatywną w niektórych jednostkach chorobowych. Głównymi wskazaniami do jego zastosowania, a także najbardziej obiecującymi, wydają się obecnie twardzina ograniczo- 
localized alopecia $[7,41]$. According to data from the literature, UVB - NB-UVB is especially recommended for children [41, 42]. A good response to NV-UVB has been shown by 77 children aged 4 to 16 treated for psoriasis, subjected to 17.5 exposures on average [42]. The initial dosage is determined on the basis of skin phototype, i.e. I, II $-0.03 \mathrm{~J} / \mathrm{cm}^{2}$, III, IV $-0.05 \mathrm{~J} / \mathrm{cm}^{2}$, with the subsequent dose increased by $10 \%$ in the next exposure [43]. Exposure to PUVA is a very rare method of treatment of paediatric patients due to proven elevated risk of carcinoma and its uncertain effect on eyesight. In special cases, it is acceptable to use PUVA therapy with preferably topic application of psoralens due to its shorter photosensitizing effect and a lesser number of side effects for the digestive system [41-43]. In Poland, oral preparations of psoralens are administered from 12 years of age, this being the age limit below which PUVA therapy cannot be used on children. In special cases, such as when preparing an vitiligo sufferer for a graft (6-8 weeks), orally administered PUVA is more effective than NB UVB [44, 45]. While the age of 12 is now the limit to the application of PUVA therapy, it can be considered on younger in special cases where its benefits outweigh risks [46]. However, as there are no randomized studies on the long-term safety of phototherapy on children, caution should be exercised and patients should be monitored $[41,45]$. The age limit for phototherapy is oftentimes set individually depending on the child's ability to remain still, degree of lesions and response to earlier methods of treatment [41].

However, there are no clear-cut guidelines to determine UV dosage for this age group. Some authors think the determination of the initial dosage for children should be made on the basis on the skin phototype, as the MED procedure may be difficult to execute than in the case of adults.

\section{PREGNANCY AND PHOTOTHERAPY}

Pregnancy is not a contraindication for the use of exposures to broadband or narrow-band UVB. NBUVB and BB-UVB therapies are considered effective and safe. The second method of choice used on pregnant women suffering from plaque psoriasis when localized treatment proves to be insufficient is UVB therapy (BB-UVB if NB-UVB is unavailable) [47, 48]. Therapy by narrow-band UVB should be considered as a first option for pregnant women suffering from a severe form of plaque psoriasis when general treatment is necessary [47] (table 8).

\section{SUMMARY}

Phototherapy/photochemotherapy is a recognized and useful treatment method for numerous skin dis- na i niektóre choroby twardzinopodobne. W leczeniu AZS jest to metoda wspomagająca u pacjentów dorosłych, zwłaszcza w okresie zaostrzeń choroby. Może być łączona z lekami stosowanymi zewnętrznie, takimi jak glikokortykosteroidy, a także z emolientami. Powinno się jednak unikać połączenia z takrolimusem i pimekrolimusem, a także ogólnie stosowaną cyklosporyną A. Średnie dawki UVA1 są skuteczne i dobrze tolerowane. Należy zaznaczyć, że metoda UVA1 jest pozbawiona objawów niepożądanych związanych np. z koniecznością zastosowania psoralenów jak w standardowej PUVA-terapii. Również ryzyko wystąpienia odczynów fototoksycznych jest znacznie niższe. Wadą jest wysoki koszt aparatury i dostępność tylko w specjalistycznych ośrodkach posiadających odpowiedni sprzęt.

Nie zaleca się łączenia fototerapii i fotochemoterapii $\mathrm{z}$ inhibitorami kalcyneuryny stosowanymi miejscowo (z wyjątkiem bielactwa), metotreksatem stosowanym ogólnie i immunosupresyjnymi lekami biologicznymi.

Bezwzglęnie przeciwwskazane jest stoswanie fototerapii i fotochemoterapii razem z cyklosporyną i azatiopryną.

\section{FOTOTERAPIA U DZIECI}

Fototerapia jest skuteczną i bezpieczną formą leczenia w populacji pediatrycznej. Najczęściej stosowana jest $\mathrm{u}$ dzieci chorych na łuszczycę, AZS, bielactwo i łysienie plackowate $[7,41]$. Zgodnie $z$ danymi $z$ piśmiennictwa u dzieci rekomenduje się przede wszystkim UVB - NB-UVB [41, 42]. Dobrą tolerancję metody NB-UVB wykazano u 77 dzieci w wieku od 4 do 16 lat leczonych z powodu łuszczycy po średnio 17,5 naświetlaniu [42]. Początkową dawkę ustala się w zależności od fototypu skóry, tj. I, II - 0,03 J/ cm², III, IV - 0,05 J/ $\mathrm{cm}^{2}$, a kolejną zwiększa się o $10 \%$ podczas następnego naświetlania [43]. Naświetlania PUVA są bardzo rzadko stosowaną metodą u dzieci ze względu na zwiększone ryzyko nowotworzenia oraz brak pewności co do pełnej i prawidłowej ochrony wzroku. W szczególnych przypadkach dopuszczalne jest stosowanie PUVA-terapii, preferuje się jednak miejscową aplikację psolarenów ze względu na krótszy efekt fotouczulający i możliwość uniknięcia objawów niepożądanych ze strony układu pokarmowego [41-43]. W Polsce preparaty doustne psolarenów są zarejestrowane od 12 . roku życia; jest to granica wieku, poniżej której nie powinno się stosować PUVA-terapii u dzieci. W szczególnych przypadkach, takich jak przygotowanie do przeszczepu w bielactwie (6-8 tygodni), lepsze wyniki od NB-UVB daje doustna PUVA [44, 45]. Mimo że obecnie wiek 12 lat jest granicą stosowania PUVA-terapii, to w niektórych przypadkach ze względu na współczynnik ryzyko/korzyść można ją rozważyć u młodszych dzieci [46]. Z uwagi na brak randomizowanych analiz dotyczących długoterminowego bezpieczeństwa foto- 
Table 8. General recommendations for preferred types of phototerapy in various diseases

\begin{tabular}{|c|c|c|c|}
\hline \multicolumn{2}{|l|}{ UVB } & PUVA & UVAI \\
\hline \multirow[t]{4}{*}{$\begin{array}{l}\text { - Psoriasis vulgaris } \\
\text { - Psoriasis of hands and feet } \\
\text { - Psoriasis inveterata } \\
\text { - Psoriatic arthritis } \\
\text { - Psoriatic erythroderma (very small doses as } \\
\text { - for phototype I and in MF) } \\
\text { - Ptopic dermatitis } \\
\text { - Pruritus } \\
\text { - Lichen nodularis } \\
\text { - Eczema microbicum and contact dermatitis } \\
\text { - Seborrheic dermatitis } \\
\text { - Pityriasis lichenoides } \\
\text { - Parapsoriasis en plaque } \\
\text { - Lymphomatoid papulosis } \\
\text { - Vitiligo } \\
\text { - Polymorphous light eruptions } \\
\text { - Pityriasis rubra pilaris }\end{array}$} & 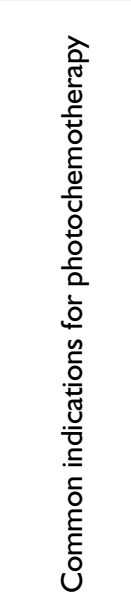 & $\begin{array}{l}\text { - Psoriasis vulgaris (guttate and } \\
\text { - Plaque psoriasis) } \\
\text { - Psoriasis of hands and feet } \\
\text { - Psoriasis inveterata } \\
\text { - Psoriatic arthritis } \\
\text { - Pityriasis lichenoides chronica } \\
\text { - Lichen planus } \\
\text { - Vitiligo } \\
\text { - Alopecia areata } \\
\text { - Graft versus host disease } \\
\text { - Generalized granuloma annulare } \\
\text { - Morphea } \\
\text { - Urticaria pigmentosa }\end{array}$ & \multirow{4}{*}{$\begin{array}{l}\text { - Morphea } \\
\text { - Atopic dermatitis } \\
\text { - Utricaria pigmentosa } \\
\text { - Eczema microbicum and contact } \\
\text { - egzema } \\
\text { - Parapsoriasis en plaque } \\
\text { - Cutaneous T-cell lymphoma - } \\
\text { - mycosis fungoides } \\
\text { - Lymphomatoid papulosis } \\
\text { - Alopecia areata } \\
\text { - Systemic sclerosis } \\
\text { - Lichen sclerosus } \\
\text { - Scleromyxedema } \\
\text { - Granuloma annulare } \\
\text { - Necrobiosis lipoidica } \\
\text { - GVHD } \\
\text { - Pityriasis rubra pilaris } \\
\text { - Utricaria pigmentosa } \\
\text { - Solar utricaria } \\
\text { - Prurigo aestivalis } \\
\text { - Polymorphous light reaction } \\
\text { - Hydroa vacciniforme }\end{array}$} \\
\hline & 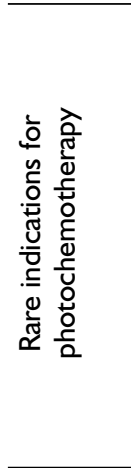 & $\begin{array}{l}\text { - Polymorphic light eruption } \\
\text { - Prurigo aestivalis } \\
\text { - Hydroa vacciniforme } \\
\text { - Actinic recticuloid } \\
\text { - Chronic actinic dermatitis } \\
\text { - Solar urticaria } \\
\text { - Prurigo nodularis } \\
\text { - Chronic hand dermatitis } \\
\text { - Histiocytosis X } \\
\text { - Transient acantholytic dermatosis } \\
\text { - Seborrheic dermatitis } \\
\text { - Itch (including itch associated with } \\
\text { polycythemia vera) }\end{array}$ & \\
\hline & 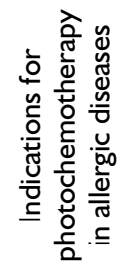 & $\begin{array}{l}\text { - Atopic dermatitis } \\
\text { - Endogenous eczema }\end{array}$ & \\
\hline & 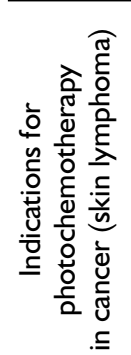 & $\begin{array}{l}\text { - Parapsoriasis en plaque } \\
\text { - Premycotic phase } \\
\text { - Mycosis fungoides } \\
\text { - Sezary syndrome } \\
\text { - Pagetoid reticulosis } \\
\text { - Lymphomatoid papulosis }\end{array}$ & \\
\hline
\end{tabular}


Tabela 8. Wskazania do fototerapii - porównanie

- Łuszczyca zwyczajna

- Łuszczyca dłoni i stóp

- Łuszczyca zadawniona

- Łuszczyca stawowa

- Erytrodermia łuszczycowa (bardzo małe dawki, jak w fototypie I i w MF)

- Atopowe zapalenie skóry

- Świąd

- Świerzbiączka guzkowa

- Liszaj płaski

- Wyprysk pieniążkowaty i kontaktowy

- Łojotokowe zapalenie skóry

- Przyłuszczyca grudkowa

- Przyłuszczyca plackowata

- Lymphomatoid papulosis

- Bielactwo

- Wielopostaciowe osutki świetlne

- Łupież czerwony mieszkowy
- Łuszczyca zwyczajna (kropelkowata i plackowata)

- Łuszczyca dłoni i stóp

- Łuszczyca zadawniona

- Łuszczyca stawowa

- Pityriasis lichenoides chronica

- Liszaj płaski uogólniony

- Bielactwo nabyte

- Łysienie plackowate

- Choroba przeszczep przeciw gospodarzowi (GVHD)

- Ziarniniak obrączkowaty rozsiany

- Morphea

- Pokrzywka barwnikowa

- Wielopostaciowe osutki świetlne

- Prurigo aestivalis

- Hydroa vacciniforme

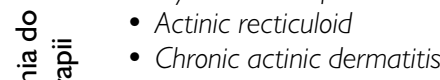

- Pokrzywka słoneczna

- Świerzbiączka guzkowa

- Chronic hand dermatitis

- Histiocytoza X

- Przejściowa dermatoza akantolityczna

- Łojotokowe zapalenie skóry

- Świąd (w tym w przebiegu czerwienicy)

- Atopowe zapalenie skóry
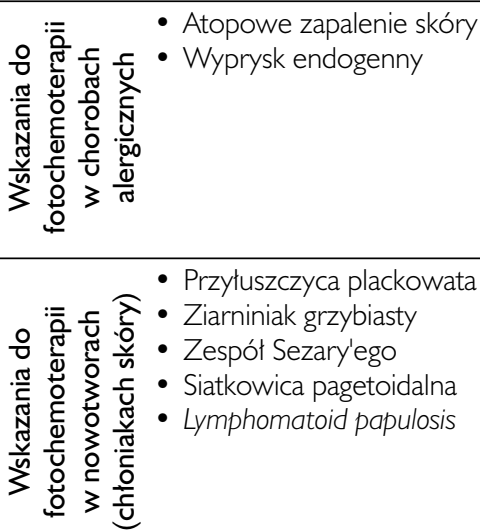

- Morphea

- Atopowe zapalenie skóry

- Pokrzywka barwnikowa

- Wyprysk pieniążkowaty i kontaktowy

- Przyłuszczyca plackowata

- Chłoniak skórny T-komórkowy

- Lymphomatoid papulosis

- Łysienie plackowate

- Twardzina układowa

- Liszaj twardzinowy

- Scleromyxedema

- Ziarniniak obrączkowy

- Obumieranie tłuszczowate

- GVHD

- Łupież czerwony mieszkowy

- Pokrzywka barwnikowa

- Pokrzywka świetlna

- Prurigo aestivalis

- Polymorphous light reaction

- Hydroa vacciniforme 
eases. If properly administered, it is highly effective with respect to patients suffering from dermatosis and susceptible to UV phototherapy/photochemotherapy. Adverse effects present extremely rarely. One if its downsides in Poland is its limited availability outside large dermatological clinics.

\section{ACKNOWLEDGMENTS}

The authors of the recommendations express their gratitude to Marta Kasprowicz-Furmańczyk MD, a resident of the Department of Dermatology, Sexually Transmitted Diseases and Clinical Immunology of the Municipal Polyclinical Hospital in Olsztyn for preparing the figure and technical assistance in editing the article.

\section{CONFLICT OF INTEREST}

The authors declare no conflict of interest. terapii u dzieci należy zachować ostrożność podczas leczenia i uważnie monitorować pacjentów [41, 45]. Granicę wieku dla fototerapii często dostosowuje się indywidualnie, biorąc pod uwagę np. ocenę, czy dziecko jest w stanie pozostać bez ruchu, nasilenie zmian chorobowych, brak odpowiedzi na wcześniejsze metody leczenia [41].

Nie ma jednak jednoznacznych wytycznych określających dawki promieniowania UV w tej grupie wiekowej. Niektórzy autorzy uważają, że do ustalenia dawki początkowej u dzieci bardziej użyteczne jest określenie fototypu skóry ze względu na fakt, że wykonanie procedury określenia MED może być trudniejsze niż u dorosłych.

\section{CIAŻ̇A A FOTOTERAPIA}

Ciąża nie stanowi przeciwwskazania do stosowania naświetlań UVB, zarówno szerokopasmowego, jak i wąskopasmowego. Terapie NB-UVB oraz BB-UVB są uważane za skuteczne i bezpieczne. Gdy leczenie miejscowe okazuje się niewystarczające, metodą drugiego wyboru u pacjentek ciężarnych z łuszczycą łagodną jest fototerapia UVB (BB-UVB, gdy NB-UVB jest niedostępne) [47, 48]. U kobiet w ciąży z ciężką łuszczycą plackowatą powinno się rozważyć terapię wąskopasmowym UVB jako leczenie pierwszego wyboru [47] (tab. 8).

\section{PODSUMOWANIE}

Fototerapia i fotochemoterapia to uznane i przydatne metody leczenia wielu chorób skóry. Jeśli są one prawidłowo prowadzone, mogą być wysoce skuteczne u chorych na dermatozy podatnych na fototerapię lub fotochemoterapię UV. Objawy niepożądane występują niezwykle rzadko. Wadą tych metod w Polsce jest ich mała dostępność poza dużymi ośrodkami dermatologicznymi.

\section{PODZIĘKOWANIE}

Zespół autorów rekomendacji składa serdeczne podziękowania lek. med. Marcie Kasprowicz-Furmańczyk, rezydentce w Katedrze i Klinice Dermatologii, Chorób Przenoszonych Drogą Płciową i Immunologii Klinicznej Miejskiego Szpitala Zespolonego w Olsztynie za wykonanie ryciny i pomoc techniczną $\mathrm{w}$ redakcji artykułu.

\section{KONFLIKT INTERESÓW}

Autorzy nie zgłaszają konfliktu interesów. 
References

Piśmiennictwo

1. Batool S., Bibi A., Frezza F., Mangini F.: Benefits and hazards of electromagnetic waves, telecommunication, physical and biomedical: a review. Eur Rev Med Pharmacol Sci 2019, 23, 3121-3128.

2. Narbutt J., Wolska H., Kaszuba A., Langner A., Lesiak A., Maj J., et al.: Photoprotection. Recommendations of the Polish Dermatological Society. Part 1: Ultraviolet radiation and sunscreens. Dermatol Rev 2018, 105, 30-40.

3. Parrish J.A., Fitzpatrick T.B., Tanenbaum L., Pathak M.A.: Photochemotherapy of psoriasis with oral methoxsalen and longwave ultraviolet light. N Engl J Med 1974, 291, 1207-1211.

4. Parrish J.A.: Phototherapy and photodermatology of skin diseases. J Invest Dermatol 1981, 77, 167-171.

5. Macfarlane L., Bhoyrul B., Ibbotson S.H., Dawe R.S.: Practice when minimal phototoxic and minimal erythema doses are not determinable. Photodermatol Photoimmunol Photomed 2015, 31, 224-226.

6. Ibbotson S.H., Bilsland D., Cox N.H., Dawe R.S., Diffey B., Edwards C., et al.: An update and guidance on narrowband ultraviolet B phototherapy: a British Photodermatology Group Workshop Report. Br J Dermatol 2004, 151, 283-297.

7. Menter A., Korman N.J., Elmets C.A.: Guidelines of car e for the management of psoriasis and psoriatic arthritis: Section 5. Guidelines of care for the treatment of psoriasis with phototherapy and photochemotherapy. J Am Acad Dermatol 2010, $62,114-135$

8. Almutawa F., Alnomair N., Wang Y., Hamzavi I., Lim H.W.: Systematic review of UV-based therapy for psoriasis. Am J Clin Dermatol 2013, 14, 87-109.

9. Wolska H.: Fototerapia (UV) w dermatologii. Wydawnictwo Czelej, Warszawa, 2006.

10. Schneider L.A., Hinrichs R., Scharffetter-Kochanek K.: Phototherapy and photochemotherapy. Clin Dermatol 2008, 26, 464476

11. Krutmann J., Hönigsmann H.: Dermatological phototherapy and photodiagnostic methods (Vol. 8). C. A. Elmets, P. R. Bergstresser (eds.). Springer, Berlin 2009.

12. Cameron H., Dawe R.S., Yule S., Murphy J., Ibbotson S.H., Ferguson J.: A randomized, observer-blinded trial of twice vs. three times weekly narrowband ultraviolet B phototherapy for chronic plaque psoriasis. Br J Dermatol 2002, 147, $973-978$.

13. Lai C., Cao H., Hearst J.E., Corash L., Luo H., Wang Y.: Quantitative analysis of DNA interstrand cross-links and monoadducts formed in human cells induced by psoralens and UVA irradiation. Anal Chem 2008, 80, 8790-8798.

14. Chaowattanapanit S., Choonhakarn C., Foocharoen C., Julanon N.: Phototherapy in systemic sclerosis: review. Photodermatol Photoimmunol Photomed 2017, 33, 296-305.

15. Suganuma K., Nakajima H., Ohtsuki M., Imokawa G.: Astaxanthin attenuates the UVA-induced up-regulation of matrixmetalloproteinase-1 and skin fibroblast elastase in human dermal fibroblasts. J Dermatol Sci 2010, 58, 136-142.

16. Wang H., Shang L., Hao W.: The induction of apoptosis and reactive oxygen species in human skin fibroblast by ultraviolet A. Beijing Da Xue Xue Bao Yi Xue Ban 2003, 35, 69-73.

17. Olsen E.A., Hodak E., Anderson T., Carter J.B., Henderson M., Cooper K., et al.: Guidelines for phototherapy of mycosis fungoides and Sézary syndrome: a consensus statement of the United States Cutaneous Lymphoma Consortium. J Am Acad Dermatol 2016, 74, 27-58.

18. Rodenbeck D.L., Silverberg J.I., Silverberg N.B.: Phototherapy for atopic dermatitis. Clin Dermatol 2016, 34, 607-613.

19. Kölgen W., Both H., van Weelden H., Guikers K.L., Bruijnzeel-Koomen C.A., Knol E.F., et al.: Epidermal Langerhans cell depletion after artificial ultraviolet B irradiation of human skin in vivo: apoptosis versus migration. J Invest Dermatol 2002, 118, 812-817.

20. Batycka-Baran A., Besgen P., Wolf R., Szepietowski J.C., Prinz J.C.: The effect of phototherapy on systemic inflammatory process in patients with plaque psoriasis. J Photochem Photobiol B 2016, 161, 396-401.

21. Sample A., Zhao B., Qiang L., He Y.Y.: Adaptor protein p62 promotes skin tumor growth and metastasis and is induced by UVA radiation. J Biol Chem 2017, 292, 14786-14795.

22. Davis I.C., Stiller M.J., Shupack J.L.: Pharmacology of therapeutic agents in photomedicine. In: Clinical Photomedicine. H.W. Lim, N.A. Soter (eds.). Routledge, New York, 2017, 59-74.

23. Gruss C., Behrens S., Reuther T., Husebo L., Neumann N., Altmeyer P., et al.: Kinetics of photosensitivity in bath-PUVA photochemotherapy. J Am Acad Dermatol 1998, 39, 443-446.

24. Foss F.M., Girardi M.: Mycosis fungoides and Sezary syndrome. Hematol Oncol Clin North Am 2017, 31, $297-315$.

25. Morison W.L., Richard E.G.: PUVA photochemotherapy and other phototherapy modalities. In: Comprehensive Dermatologic Drug Therapy. $3^{\text {rd }}$ edn S.E. Wolverton (ed.), Saunders Elsevier, Philadelphia 2013.

26. Morison W.L.: Phototherapy and photochemotherapy for skin disease. CRC Press, Boca Raton, 2005.

27. Lim H., Silpa-archa N., Amadi U., Menter A., Van Voorhees A.S., Lebwohl M.: Phototherapy in dermatology: a call for action. J Am Acad Dermatol 2015, 72, 1078-1080.

28. McKenna K., Ibbotson S.: Principles of phototherapy. In: Rook's Textbook of Dermatology. $9^{\text {th }}$ ed. C. Griffiths, J. Barker, T. Bleiker, et al. (eds.). Wiley Blackwell, UK 2016, 1-21.

29. Placek W., Jasiel-Walikowska E., Wrzołek T.: Ultrastructural changes after long-term PUVA-therapy. J Eur Acad Dermatol Venereol 1997, 9, S139

30. Krutmann J., Czech W., Diepgen T., Niedner R., Kapp A., Schöpf E.: High-dose UVA1 therapy in the treatment of patients with atopic dermatitis. J Am Acad Dermatol 1992, 26, 225-230.

31. Kroft E.B., Berkhof N.J., van de Kerkhof P.C., Gerritsen R.M., de Jong E.M.: Ultraviolet A phototherapy for sclerotic skin diseases: a systematic review. J Am Acad Dermatol 2008, 59, 1017-1030.

32. Kulms D., Schwarz T.: Molecular mechanisms of UV-induced apoptosis. Photodermatol Photoimmunol Photomed 2000, $16,195-201$.

33. Smit N., Musson R., Romijn F., Van Rossum H., Van Pelt J.: Effects of ultraviolet A1 radiation on calcineurin activity and cytokine production in (skin) cell cultures. Photochem Photobiol 2010, 86, 360-366. 
34. Gruss C., Reed J.A., Altmeyer P., McNutt N.S., Kerscher M.: Induction of interstitial collagenase (MMP-1) by UVA-1 phototherapy in morphea fibroblasts. Lancet 1997, 350, 1295-1296.

35. York N.R., Jacobe H.T.: UVA1 phototherapy: a review of mechanism and therapeutic application. Int J Dermatol 2010, 49, 623-630.

36. Rombold S., Lobisch K., Katzer K., Grazziotin T.C., Ring J., Eberlein B.: Efficacy of UVA1 phototherapy in 230 patients with various skin diseases. Photodermatol Photoimmunol Photomed 2008, 24, 19-23.

37. Jacobe H.T., Cayce R., Nguyen J.: UVA1 phototherapy is effective in darker skin: a review of 101 patients of Fitzpatrick skin types I-V. Br J Dermatol 2008, 159, 691-696.

38. Cadet J., Douki T., Ravanat J.L., Di Mascio P.: Sensitized formation of oxidatively generated damage to cellular DNA by UVA radiation. Photochem Photobiol Sci 2009, 8, 903-911.

39. Ikehata H., Kawai K., Komura J.I., Sakatsume K., Wang L., Imai M., et al.: UVA1 genotoxicity is mediated not by oxidative damage but by cyclobutane pyrimidine dimers in normal mouse skin. J Invest Dermatol 2008, 128, $2289-2296$.

40. Calzavara-Pinton P., Monari P., Manganoni A.M., Ungari M., Rossi M., Gualdi G., et al.: Merkel cell carcinoma arising in immunosuppressed patients treated with high-dose ultraviolet A1 (320-400 nm) phototherapy: a report of two cases. Photodermatol Photoimmunol Photomed 2010, 26, 263-265.

41. Crall C.S., Rork J.F., Delano S., Huang J.T.: Phototherapy in children: considerations and indications. Clin Dermatol 2016, 34, 633-639.

42. Napolitano M., Megna M., Balato A., Ayala F., Lembo S., Villani A., et al.: Systemic treatment of pediatric psoriasis: a review. Dermatol Ther 2016, 6, 125-142.

43. Pašić A., Čeović R., Lipozenčić J., Husar K., Sušić S.M., Skerlev M., Hrsan D.: Phototherapy in pediatric patients. Pediatr Dermatol 2003, 20, 71-77.

44. Ling T.C., Clayton T.H., Crawley J., Exton L.S., Goulden V., Ibbotson S., et al.: British Association of Dermatologists and British Photodermatology Group guidelines for the safe and effective use of psoralen-ultraviolet A therapy 2015. Br J Dermatol 2016, 174, 24-55.

45. Ersoy-Evans S., Altaykan A., Şahin S., Kölemen F.: Phototherapy in childhood. Pediatr Dermatol 2008, 25, 599-605.

46. Lesiak A., Olejniczak-Staruch I., Rogowski-Tylman M., Sysa-Jędrzejowska A., Słowik-Kwiatkowska I., Narbutt J.: Postać dziecięca lymphomatoid papulosis - opis przypadku. Dermatol Klin 2013, 15, 28-31.

47. Hoffman M.B., Farhangian M., Feldman S.R.: Psoriasis during pregnancy: characteristics and important management recommendations. Expert Rev Clin Immunol 2015, 11, 709-720.

48. Bae Y.S.C., Van Voorhees A.S., Hsu S., Korman N.J., Lebwohl M.G., Young M., et al.: Review of treatment options for psoriasis in pregnant or lactating women: from the Medical Board of the National Psoriasis Foundation. J Am Acad Dermatol 2012, 67, 459-477.

Received: 22.03 .2019

Accepted: 30.03.2019

Otrzymano: 22.03.2019 r.

Zaakceptowano: 30.03.2019 r.

Placek W., Kaszuba A., Lesiak A., Maj J., Narbutt J., Osmola-Mańkowska A., Wolska H., Rudnicka L.: Phototherapy and photochemotherapy in dermatology. Recommendations of the Polish Dermatological Society. Dermatol Rev/Przeg1 Dermatol 2019, 106, 237-256. DOI: https://doi.org/10.5114/dr.2019.86906. 